\title{
E-Learning Delivery Methods: Predictors of Satisfaction by Students of Nigerian Universities
}

\author{
Janet O. Adekannbi \\ Africa Regional Centre for Information Science, University of Ibadan, Nigeria \\ E-Mail: janet.adekannbi@gmail.com
}

\begin{abstract}
Learners' satisfaction is an important factor to the success of any e-learning programme. This study presents findings from students' assessment of the e-learning platforms used at Distance Learning Centre University of Ibadan, Nigeria. Survey design was used. Data was collected from 351 students in 100 and 200 levels of the Centre using the questionnaire. Frequency and percentage distribution were used for descriptive statistics, while, multiple regression was performed to test the hypotheses. The results showed that Information quality, system quality and service quality were not significant predictors of student's satisfaction except with the Email where information and service quality influenced overall satisfaction. Challenges to students' use of the platforms include inadequate power supply, poor telecommunication network, high cost of self-provided power supply and high cost of owning and maintaining e-learning devices.
\end{abstract}

Keywords: E-learning Delivery Methods, Satisfaction, Distance Learning, Delone and Mclean IS Model

\section{INTRODUCTION}

The need to provide quality education for everyone has led to the introduction of Information and Communication Technology (ICT) into educational systems worldwide. Hence, ICT is now present at all levels of education, providing teachers and students access to vast stores of knowledge (Ilechukwu, 2013; UNESCO, 2011). Although the use of ICT has various applications in learning, the most direct application is in the area of e-learning (Ilechukwu, 2013).The term 'e-learning' has been widely used in education since the mid-1990s, however, the definition continues to be a subject for discussion among researchers. Many researchers accept e-learning as the delivery of teaching materials via electronic media, such as Internet, Intranets, Extranets, satellite broadcast, audio/video tape, interactive TV, and CD-ROM (Engelbrecht, 2005). Hence, e-Learning can simply be defined as the use of telecommunication technology to deliver information for education and training (Sun et al., 2008). However, beyond the issue of definition, the success of any good e-learning services lies in its being able to address learners' needs and educational objectives (Liaw, 2008).

According to Ali and Ahmad (2011), the satisfaction of a student with e-learning instructional medium is a function of his/her level of pleasure as well as the effectiveness of the education that the student experiences. Studies have shown that the learner's satisfaction is an important factor to the success of any distance education program (Ayub and Iqbal, 2011). However, despite the rapid growth of elearning in Nigeria, little empirical studies have been carried out to investigate the level of students' satisfaction with this instructional medium. An assessment of students' satisfaction with the e-learning techniques used by the Distance Learning Centre University of Ibadan is necessary for designing adequate and effective intervention in delivering course modules.

Among the various models that attempted to identify the factors that influence user satisfaction and the success of an information system, the Information Systems Success Model by Delone and McLean (1992; 2003) is deemed as one of the most comprehensive models. DeLone and McLean (2003) identified six dimensions of success factors, namely, system quality, information quality, service quality, use, user satisfaction, and net benefit (Machado-DaSilva et al., 2014). System quality refers to aspects of the information system itself, such as processing speed, ease of use, necessary requirements, navigability, adaptability, availability, reliability, usability and response time. These characteristics are assumed to be valued by users of a system. Information quality refers to the quality of the content stored in the system. In this case, it includes factors such as the quality of graphs and data, and the clarity with which the information is presented to users. Information quality captures the content issues that are geared toward providing users with personalized, complete, relevant, easyto-understand, and secure information. Service quality is essential to implementing the information system, as some essential services are fundamental, such as user training, a help desk, and support. The quality of the services depends on the performance of those who provide them at the moment they are delivered. Services can be offered either through the information system itself or offline (MachadoDa-Silva et al., 2014).

The user's perception of and attitude towards the environment as a whole reflects the concept of user satisfaction (Machado-Da-Silva et al., 2014). According to Kranzow (2013), if students are satisfied with their online experiences, they would be more likely to remain in their program. Previous studies have reported on the factors influencing students' satisfaction with online course delivery (Iftakhar 2016; Shaharanee et al., 2016; Laumer et al., 2017). Ali and Ahmad (2011) examined the key factors 
for determining students' satisfaction with distance learning courses in an Open University in Pakistan. Findings showed that student-instructor interaction, instructor's performance and course evaluation have strong positive relationship with students' satisfaction. In Brazil, MachadoDa-Silva et al., (2014) using 291 students from public and private institutions registered in an online programme investigated factors influencing user satisfaction. Based on Delone and Mclean (2003) Information Systems Success Model, the study reported that user satisfaction construct had $89 \%$ of variance explained by information quality and service quality, whereas system quality had no predictive power on user satisfaction. Olatokun and Mala (2011) also conducted a research to assess students' satisfaction with elearning at the National Open University of Nigeria (NOUN) in order to determine the factors that influence their intention to use e-learning. Three constructs namely; system quality, information quality, service quality in Delone and Mclean Information System Success (ISS) model were used to determine user satisfaction and intention to use e-learning. Results showed that system quality and service quality were significant contributors to students' satisfaction while information quality did not contribute to students' satisfaction.

Olatokun and Mala (2011) is only one of the very few studies that have assessed users' satisfaction with e-learning among Nigerian distance learners using Delone and Mclean (1992) model. Distance education continues to grow in Nigeria as many universities continue to establish distance learning centres in response to one of the major objectives of the Nigerian National Policy on Education: providing equal educational opportunities to all citizens at all levels of education, thus widening participation in education. Moreover, the National Universities Commission (NUC) policy guidelines (NUC 2009) for open and distance learning in Nigerian universities encourage the use of technology in deploying distance education programs. This has necessitated huge investments in ICT by Nigerian universities in order to facilitate effective and satisfactory elearning delivery.

The Distance Learning Centre, University of Ibadan, was established in 2002 to serve the needs of both young and adult distance learners, whether currently employed or seeking employment. The Centre has continued to actively improve on the use of ICT in e-learning delivery in its resolve to build a Centre that would move from the provision of open distance learning to becoming a Centre of excellence in Africa. Towards achieving this, the Centre introduced the DLC android tablets to all new students. The device houses all students' course materials and provides the platform for all activities including tutorials and continuous assessments. Students can work on their devices both online and offline. These customized tablets contain 7 applications for e-learning course delivery, namely: LMS, Edmodo, Google classroom, Google Hangout, DLC Email, You Tube and Whatsapp.
After three years of introduction of these android tablets and considering the huge investment involved, there is a need to investigate the satisfaction of students with these e-learning delivery methods as well as factors responsible for students' satisfaction or dissatisfaction. This study adapted Delone and Mclean (2003) model for assessing students' satisfaction with e-learning course delivery methods at Distance Learning Centre, University of Ibadan. The study investigated information quality, service quality and system quality as predictors of students' satisfaction with each of the 6 delivery methods. Hence, this study provides answers to the following questions:

1. What are the factors responsible for students' satisfaction or dissatisfaction when instructed through these e-learning methods?

2. What are the challenges faced by the DLC students of University of Ibadan in the use of these e-learning platforms.

The following hypotheses were also tested to investigate the influence of information quality, service quality and system quality on overall satisfaction with each of the e-learning platform.

$H_{01}$ : System quality of the e-learning platform does not significantly influence students' overall satisfaction.

$H_{02}$ : Information quality of the e-learning platform does not significantly influence students' overall satisfaction.

$H_{03}$ : Service quality of the e-learning platform does not significantly influence students' overall satisfaction.

The remainder of this paper discusses the research methodology and data analysis for the study; presents the results and discussion of findings; and ends with conclusion and recommendations based on findings from the study.

\section{RESEARCH METHODOLOGY AND DATA ANALYSIS}

Survey research design using the quantitative approach was employed for this study. The study population comprised both 100 and 200 level students of Distance Learning Centre University of Ibadan. These two levels were purposively selected because all the e-learning delivery methods this research assessed were used by students in only these two levels. The students were approached for this study at the end of the session by which time they had used their tablets containing the 7 e-learning platforms for minimum of two semesters.

Multistage sampling was used in selecting respondents. The first stage involved division of students in each level into their various departments. According to Gay and Diehl (1992) and Alreck and Settle (1995), for descriptive research the sample should be $10 \%$ of population. But if the population is small then $20 \%$ may be required. Hence, considering the relatively large population, the sample size of $10 \%$ was considered adequate for the study (Table I). 
TABLE I DISTRIBUTION OF POPULATION AND SELECTED SAMPLE SIZE

\begin{tabular}{|l|c|c|c|c|}
\hline \multirow{2}{*}{ Department } & \multicolumn{2}{|c|}{ Population } & \multicolumn{2}{c|}{ Selected samples } \\
\cline { 2 - 5 } & $\mathbf{1 0 0}$ & $\mathbf{2 0 0}$ & $\mathbf{1 0 0}$ & $\mathbf{2 0 0}$ \\
\hline English & 113 & 80 & 11 & 8 \\
\hline Philosophy & 104 & 85 & 10 & 9 \\
\hline Political science & 559 & 255 & 56 & 26 \\
\hline Psychology & 796 & 183 & 80 & 18 \\
\hline Economics & 444 & 487 & 44 & 49 \\
\hline Social work & 437 & 327 & 44 & 33 \\
\hline \multicolumn{2}{|c|}{3870} & \multicolumn{3}{c|}{388} \\
\cline { 2 - 5 } Total & 2453 & 1417 & 245 & 143 \\
\cline { 2 - 5 } & \multicolumn{3}{|c|}{ Source: Database office of the Distance Learning Centre, }
\end{tabular}

University of Ibadan. 2016

The data collection instrument was a questionnaire which was adapted from Olatokun and Mala (2011). Questionnaire is the most commonly used research instrument because it provides quick and efficient way of obtaining large amounts of information from a large sample of people, responses are gathered in a standardized way and more objective and easy to analyze. The questionnaire contained open and closed ended questions that were divided into three sections. The sections were designed to elicit information on the following variables:

A. Demographic Data: The first part of the questionnaire gathered information pertaining to the participants' demographic characteristics such as age, gender, level of study, department, marital status, highest educational qualification, employment status.

B. Assessment of Each E-Learning Delivery Method: This section identified the available e-learning delivery methods and assessed each in terms of system quality, service quality, information quality and overall satisfaction. It also contained open ended questions to determine the factors responsible for students' satisfaction or dissatisfaction.

C. Challenges in Using E-Learning Delivery Method: This section collected data on challenges faced by the students in using the e-learning platforms. The reliability of the constructs, system quality, service quality, information quality was tested and all the variables showed Cronbach Alpha values above 0.7. The questionnaire copies were administered during one of the interactive sessions held by the Centre. Such interactive sessions are usually held once in a semester and most students are present for them. In all, 388 copies of questionnaire were administered and 351 copies returned which translates to a return rate of $90.5 \%$ achieved. Collected data were coded and analyzed using Statistical Package Software for Social Sciences (SPSS). Both descriptive and inferential statistics were used for analyses. Frequency and percentage distribution were used for descriptive statistics, while multiple regression analysis was performed to test the hypotheses. Responses to the open ended questions which generated qualitative data were analysed thematically.

\section{RESULTS}

\section{A. Demographic Characteristics of Respondents}

A total of 351 students participated in the study. Table II shows that $53.6 \%$ and $46.4 \%$ of respondents constituted male and female respectively and $76.1 \%$ and $22.8 \%$ were single and married respectively, while $1.1 \%$ were divorced. Also 59.3\% of the respondents had SSCE, while $31.9 \%$ had OND as their highest educational qualification. The respondents with HND were $5.4 \%$ while $3.4 \%$ had University degree. About $80 \%$ of the respondents were between 21-30 years whereas less than 10\% were between 31-40 years. Almost $70 \%$ of the respondents were unemployed.

TABLE II DEMOGRAPHIC CHARACTERISTICS OF RESPONDENTS

\begin{tabular}{|c|c|c|c|}
\hline Variable & Category & Frequency & $\%$ \\
\hline \multirow{2}{*}{ Gender } & Male & 188 & 53.6 \\
\hline & Female & 163 & 46.4 \\
\hline \multirow{5}{*}{ Age } & $16-20$ & 46 & 13.1 \\
\hline & $21-25$ & 159 & 45.3 \\
\hline & $26-30$ & 112 & 31.9 \\
\hline & $31-35$ & 30 & 8.5 \\
\hline & $36-40$ & 4 & 1.1 \\
\hline \multirow{3}{*}{ Marital Status } & Single & 267 & 76.1 \\
\hline & Married & 80 & 22.8 \\
\hline & Divorced & 4 & 1.1 \\
\hline \multirow{4}{*}{$\begin{array}{l}\text { Educational } \\
\text { Qualification }\end{array}$} & SSCE & 208 & 59.3 \\
\hline & National Diploma & 112 & 31.9 \\
\hline & HND & 19 & 5.4 \\
\hline & $\begin{array}{l}\text { University } \\
\text { Degree }\end{array}$ & 12 & 3.4 \\
\hline \multirow{2}{*}{ Level } & 100 & 221 & 63 \\
\hline & 200 & 130 & 37 \\
\hline \multirow{6}{*}{ Department } & English & 18 & 5.1 \\
\hline & Philosophy & 18 & 4.8 \\
\hline & Political Science & 76 & 20.3 \\
\hline & Psychology & 87 & 23.3 \\
\hline & Economics & 81 & 21.7 \\
\hline & Social Work & 71 & 19 \\
\hline \multirow{2}{*}{$\begin{array}{l}\text { Employment } \\
\text { Status }\end{array}$} & Employed & 121 & 34.5 \\
\hline & Not employed & 230 & 65.5 \\
\hline
\end{tabular}

B. Factors Responsible for Students' Satisfaction/ Dissatisfaction when instructed through these E-Learning Platforms: Responses from qualitative data were grouped by themes to form eight categories. Factors responsible for student's satisfaction are: 
1. Positive and Timely Response from Instructors: A number of respondents reported that timely helpful communication with their lecturers and fast response to queries influenced their satisfaction with the delivery methods. However, majority of the respondents were more satisfied with the Email. Their responses include:

"I am satisfied because this is the only place lecturers actually respond to me at least once in a while" (Female, 100 level, 21-25 years, Philosophy. (Email))

2. Accurate and Adequate Information: Respondents reported that the accuracy and adequacy of information they get from some platforms like Google classroom, Google hangouts, E-mail influenced their satisfaction with the platforms.

"I rate this very satisfied because all the materials I get on this platform are very correct. I am satisfied" (Female, 200 level, 21-25 years, English. (Google classroom))

3. Cost of Internet Subscription: Cost of internet datawas stated to be one of the factors that contributed to the students' satisfaction. Respondents were satisfied with Email, Google classroom, WhatsApp because they consume less internet data compared to other platforms like YouTube and Google hangouts. "This is the best, I think all lecturers should use this email. It is very cheap compared to others and very reliable" (Female, 100 level, 21-25 years, Psychology (Email))

4. Ease of Use: Respondents reported that Google classroom, E-mail, WhatsApp are easy to use and this influenced their satisfaction.

"Because the platform is very easy to understand" (Male, 200 level, 26-30years, Political Science (Google classroom)) "In my own opinion this is an easy method but not regulated. Our lecturers should improve this" (Male, 100 level, 21-25 years, English (WhatsApp)).

Factors Responsible for Students' Dissatisfaction are
1. Lack of Clarity of Information: Respondents also stated that information on some platforms is not clear and this makes them dissatisfied with these methods. This was especially reported about LMS.

"I am rating this not satisfied because my courses are not clear here" (Female, 200 level, 21-25 years, Philosophy (LMS))

2. Complexity of E-Learning Platform: Some respondents however, reported that platforms like Google hangouts, LMS, Edmodo are not easy to set up and use which contributed to their dissatisfaction with them.

"I am very dissatisfied with this method because I don't understand it and it is not easy to use for me" (Male, 100 level, 31-35years, Political Science, (Edmodo))

3. Outdated Information: Outdated information was also stated by the respondents as one of the factors that caused their dissatisfaction. LMS was specifically said to contain outdated information.

"Yes! I so much love this application the only reason I have issue here is that it was not up to date during our second semester"(Male, 100 level, 31-35years, Psychology, LMS))

4. Abuse of E-Learning Platform by Students: E-learning platforms like WhatsApp were reportedly being constantly abused by students as many use them for non-academic purposes. WhatsApp was not regarded as effective for teaching and learning.

"In my candid opinion about whatsapp most DLC students abuse this platform so I can't give this platform a higher rating" (Male, 31-35 yrs, 100 level, Psychology (WhatsApp)

C. Challenges Faced in the Use of these E-Learning Platforms: Table III highlights the challenges faced by the respondents in the use of the seven e-learning delivery platforms.

TABLE III CHALLENGES FACED IN THE USE OF E-LEARNING DELIVERY PLATFORMS

\begin{tabular}{|c|c|c|c|c|}
\hline \multirow{2}{*}{ Challenges } & \multicolumn{4}{|c|}{ Response \% } \\
\hline & SD & D & $\mathbf{A}$ & $\mathbf{S A}$ \\
\hline Lack of adequate and appropriate infrastructure & 22.2 & 24.5 & 25.6 & 27.6 \\
\hline High cost of acquiring e-learning tools & 24.9 & 41.5 & 15.8 & 17.8 \\
\hline Poor telecommunication/ network services & 13.7 & 22.2 & 33.3 & 30.8 \\
\hline Inadequate power supply & 13.1 & 19.4 & 42.5 & 25.1 \\
\hline High cost of owing digital device e.g tabs, smartphones, laptops & 13.1 & 29.6 & 34.2 & 23.1 \\
\hline Poor orientation towards the use of ICT in education & 16.1 & 33.3 & 29.3 & 20.8 \\
\hline Inappropriate skills to use e-learning resources or facilities effectively & 17.1 & 32.5 & 29.1 & 21.4 \\
\hline High cost of maintain e-learning devices and services & 12.3 & 29.3 & 29.3 & 29.1 \\
\hline High cost self-provided power supply (generators) & 16.2 & 21.7 & 29.6 & 32.2 \\
\hline High cost of internet connectivity & 17.7 & 28.5 & 19.7 & 34.2 \\
\hline
\end{tabular}


This finding was also supported by responses from the open-ended questions:

"I think the major challenge we have in this country is the poor internet and yet it is very expensive, this affects me" (Female, 21-25yrs, 100 level, Philosophy). "Internet network very expensive and Power Holding Company is also not helping matters" (Male, 26-30yrs, 200 level, Political science)

The following are rated highest as challenges faced by distance learners in using the e-learning delivery methods

1. Inadequate power supply $(67.6 \%)$

2. Poor telecommunication network $(64.1 \%)$

3. High cost of self-provided power supply (61.8\%)

4. High cost of maintaining e-learning devices and services $(58.4 \%)$

TABLE IV RESUlt OF REgRESSION ANALYSIS FOR HyPOTHESES 1-3

\begin{tabular}{|c|c|c|c|c|c|}
\hline \multirow{2}{*}{ Delivery Methods } & \multirow{2}{*}{ Independent Variables } & \multicolumn{3}{|c|}{ Overall students satisfaction with Delivery Method } & \multirow{2}{*}{ Decision } \\
\hline & & B & Beta & Sig & \\
\hline \multirow{3}{*}{ Google Classroom } & System Quality & 0.056 & 0.230 & 0.403 & $\begin{array}{c}\text { Hypothesis } 1 \\
\mathrm{H}_{\mathrm{o}} \text { Not rejected }\end{array}$ \\
\hline & Information Quality & 0.193 & 0.228 & 0.397 & $\begin{array}{c}\text { Hypothesis } 2 \\
\mathrm{H}_{\mathrm{o}} \text { Not rejected }\end{array}$ \\
\hline & Service Quality & -0.136 & -0.081 & 0.403 & $\begin{array}{c}\text { Hypothesis } 3 \\
\mathrm{H}_{\mathrm{o}} \text { Not rejected }\end{array}$ \\
\hline \multirow{3}{*}{ Google Hangout } & System Quality & -0.254 & 0.092 & 0.338 & $\begin{array}{c}\text { Hypothesis } 1 \\
\mathrm{H}_{\mathrm{o}} \text { Not rejected }\end{array}$ \\
\hline & Information Quality & 0.214 & 0.088 & 0.482 & $\begin{array}{c}\text { Hypothesis } 2 \\
\mathrm{H}_{\mathrm{o}} \text { Not rejected }\end{array}$ \\
\hline & Service Quality & -0.162 & -0.114 & 0.296 & $\begin{array}{c}\text { Hypothesis } 3 \\
\mathrm{H}_{\mathrm{o}} \text { Not rejected }\end{array}$ \\
\hline \multirow{3}{*}{ Email } & System Quality & -0.152 & -0.066 & 0.339 & $\begin{array}{c}\text { Hypothesis } 1 \\
\mathrm{H}_{\mathrm{o}} \text { Not rejected }\end{array}$ \\
\hline & Information Quality & 0.766 & 0.344 & 0.000 & $\begin{array}{l}\text { Hypothesis } 2 \\
\mathrm{H}_{\mathrm{o}} \text { Rejected }\end{array}$ \\
\hline & Service Quality & -0.547 & -0.386 & 0.000 & $\begin{array}{l}\text { Hypothesis } 3 \\
\mathrm{H}_{\mathrm{o}} \text { Rejected }\end{array}$ \\
\hline \multirow{3}{*}{ YouTube } & System Quality & -0248 & 0.089 & 0.419 & $\begin{array}{c}\text { Hypothesis } 1 \\
\mathrm{H}_{\mathrm{o}} \text { Not rejected }\end{array}$ \\
\hline & Information Quality & -0.014 & -0.006 & 0.957 & $\begin{array}{c}\text { Hypothesis } 2 \\
\mathrm{H}_{\mathrm{o}} \text { Not rejected }\end{array}$ \\
\hline & Service Quality & 0.208 & -0100 & 0.364 & $\begin{array}{c}\text { Hypothesis } 3 \\
\mathrm{H}_{\mathrm{o}} \text { Not rejected }\end{array}$ \\
\hline \multirow{3}{*}{ WhatsApp } & System Quality & -0.415 & -0.153 & 0.115 & $\begin{array}{c}\text { Hypothesis } 1 \\
\mathrm{H}_{\mathrm{o}} \text { Not rejected }\end{array}$ \\
\hline & Information Quality & 0.305 & 0.136 & 0.161 & $\begin{array}{c}\text { Hypothesis } 2 \\
\mathrm{H}_{\mathrm{o}} \text { Not rejected }\end{array}$ \\
\hline & Service Quality & -0.136 & -0.102 & 0.269 & $\begin{array}{c}\text { Hypothesis } 3 \\
\mathrm{H}_{\mathrm{o}} \text { Not rejected }\end{array}$ \\
\hline \multirow{3}{*}{ LMS } & System Quality & 0.167 & -0.059 & 0.526 & $\begin{array}{c}\text { Hypothesis } 1 \\
\mathrm{H}_{\mathrm{o}} \text { Not rejected }\end{array}$ \\
\hline & Information Quality & 0.308 & 0.142 & 0.132 & $\begin{array}{c}\text { Hypothesis } 2 \\
\mathrm{H}_{\mathrm{o}} \text { Not rejected }\end{array}$ \\
\hline & Service Quality & 0.182 & -0.093 & 0.307 & $\begin{array}{c}\text { Hypothesis } 3 \\
\mathrm{H}_{\mathrm{o}} \text { Not rejected }\end{array}$ \\
\hline \multirow{3}{*}{ Edmodo } & System Quality & -0.306 & -0.106 & 0.343 & $\begin{array}{c}\text { Hypothesis } 1 \\
\mathrm{H}_{\mathrm{o}} \text { Not rejected }\end{array}$ \\
\hline & Information Quality & 0.310 & 0.141 & 0.207 & $\begin{array}{c}\text { Hypothesis } 2 \\
\mathrm{H}_{\mathrm{o}} \text { Not rejected }\end{array}$ \\
\hline & Service Quality & -0.145 & -0.071 & 0.501 & $\begin{array}{c}\text { Hypothesis } 3 \\
\mathrm{H}_{\mathrm{o}} \text { Not rejected }\end{array}$ \\
\hline
\end{tabular}

5. High cost of owning digital devices e.g. tabs, smartphones, laptops $(57.3 \%)$

6. High cost of internet connectivity (53.9\%)

7. Lack of adequate and appropriate infrastructure (53.2\%)

\section{Test of Hypotheses}

This section presents the results for the test of hypotheses. For Hypotheses 1-3, the independent variables are information quality, system quality and service quality, while the dependent variable is overall satisfaction. Multiple regression analysis was used to test Hypotheses 1-3. The pre-set level of significance for all hypotheses in this study is 0.0.5. Table IV presents the results of the regression analysis for Hypotheses 1-3. 
$H_{01}$ : System quality of the e-learning platform does not significantly influence students' overall satisfaction.

As observed in Table IV, for all the seven delivery platforms, system quality did not significantly influence overall students' satisfaction. Hence $\mathrm{H}_{\mathrm{o}}$ was not rejected.

$H_{02}$ : Information quality of the e-learning platform does not significantly influence students' overall satisfaction.

Information quality of six delivery platforms did not significantly influence overall students' satisfaction. The exception was observed in the Email where information quality significantly influenced students' overall satisfaction.

$H_{03}$ : Service quality of the e-learning platform does not significantly influence students' overall satisfaction.

Service quality of six delivery platforms did not significantly influence overall students' satisfaction. The exception was observed in the Email where service quality significantly influenced students' overall satisfaction.

\section{DISCUSSION OF FINDINGS AND CONCLUSION}

Findings from this study revealed that system quality of the e-learning platform did not significantly influence students' satisfaction. System quality refers to aspects of the information system itself, such as processing speed, ease of use, navigability, response time, system reliability. These are important factors in determining user satisfaction. However, findings from this study correlate with Machado, et al., (2014) where the authors found that there are indications that the perception of the system quality does not directly affect user satisfaction. The implication of this finding is that if students of DLC, University of Ibadan perceive that a system has good quality, there is still no guarantee that they will be satisfied with it. However, contrary findings were observed in the studies of Olatokun and Mala (2011) where a significant relationship was found between system quality of the e-learning system and student's satisfaction among distant learners of National Open University Nigeria. Information quality did not significantly influence students' satisfaction with the elearning platforms with the exception of the Email. Information quality consists of a range of attributes including accuracy, timeliness, reliability, relevance, format, and perceived usefulness, and understandability, adequacy, sufficiency. The relationship between information quality and users satisfaction has been established in studies like Koivumaki et al., (2008) and Laumer et al., (2017) where consistent relationship was found between users satisfaction and information quality of the system.

Service quality also did not significantly influence students' satisfaction except in the Email where a negative but significant relationship was surprisingly observed. The implication of this result is that the quality of support distance learners receive on all the e-learning delivery methods in form of user training, easy access and general reliability is not sufficient to influence the overall satisfaction with the e-learning delivery methods. This is in contrast to Ali and Ahmad (2011) which reported that student-instructor interaction, instructor's performance and course evaluation have strong positive relationship with students' satisfaction. It remains a surprise though, that the probability of a student being satisfied with the Email decreases with increase in the service quality.

Challenges faced by respondents in using the delivery methods included inadequate power supply, poor telecommunication network, high cost of self-provided power supply, high cost of maintaining e-learning devices and services, high cost of owning digital devices, high cost of internet connectivity and lack of adequate and appropriate infrastructure . In the study carried out by Olutola and Olatoye (2015), Ajadi et al., (2008), these authors found out that irregular power supply, high cost of internet service, poor telecommunication network, high cost of e-learning software and hardware are challenges affecting e-learning delivery in Nigeria. Oye (2011) also supported the fact that cost of accessing the internet, irregular and frequent interrupted power supply and limited expertise/ inadequate personnel, are challenges faced by students in using e-learning platforms in Nigeria.

This study has revealed the need for DLC University of Ibadan to review the technology used for e-learning delivery especially in view of the fact that information and communication technologies keep evolving. The study suggests that the Centre should focus on technologies that the students are more satisfied with rather than having so many of these delivery platforms that are not actively used by students for learning. Distance learners who are not yet attuned to using these methods can be helped through improved training and increased awareness.

\section{REFERENCES}

[1] Ajadi, T.O., Salawu, I.O. \& Adeoye, F.A. (2008). E-learning and Distance Education in Nigeria. International Online Journal of Educational Technology, 7(4), 2-16.

[2] Ali, A. \& Ahmad, I. (2011). Key factors for determining students' satisfaction in distance learning courses: A study of Allama Iqbal Open University. Journal of Contemporary Educational Technology, 22(2), 118-134.

[3] Alreck, P.L. \& Settle, R.B. (1995) The Survey Research Handbook, 2nd edition. Chicago: Irwin.

[4] Ayub, N. \& Iqbal, S. (2011). Student satisfaction with e-Learning achieved in Pakistan. Asian Journal of Distance Education, 9(2), 2631.

[5] Delone, W.H. \& Mclean, E.R. (1992). Information systems success: The quest for the dependent variable. Information Systems Research, 50(2), 60-95.

[6] DeLone, W.H. \& McLean, E.R. (2003). The DeLone and McLean model of information systems success: A ten-year update. Journal of Management Information Systems, 19(4), 9-30.

[7] Engelbrecht, E. (2005). Adapting to changing expectations: Postgraduate students' experience of an e-learning tax program. Computers and Education, 45(2), 217-229. 
[8] Gay, L.R. \& Diehl, P.L. (1992). Research Methods for Business and Management. New York:Macmillan.

[9] Iftakhar, S. (2016). Google classroom: What works and how? Journal of Education and Social Sciences, 3, 12-18.

[10] Ilechukwu, L.C. (2013). The assessment of utilization of e-Learning opportunities for effective teaching and learning of religion in Nigerian tertiary institutions. European Journal of Educational Studies, 5(3), 343-359.

[11] Koivumaki, T., Ristola, A., \& Kesti, M. (2008). The effects of information quality of mobile information services on user satisfaction and service acceptance-empirical evidence from Finland. Behaviour \& Information Technology, 27(5), 375-385.

[12] Kranzow, J. (2013). Faculty leadership in online education: Structuring courses to impact student satisfaction and persistence. Journal of Online Learning and Teaching, 9(1), 131-139.

[13] Laumer, S., Maier, C., \& Weitzel, T. (2017). Information quality, user satisfaction, and the manifestation of workarounds: A qualitative and quantitative study of enterprise content management system users. European Journal of Information Systems, 1-28. doi:10.1057/s41303-016-0029-7

[14] Liaw, S.S. (2008). Investigating students' perceived satisfaction, behavioral intention, and effectiveness of e-Learning: A case study of the Blackboard system. Computers \& Education, 51(2), 864-873.

[15] Machado-Da-Silva, F. N., Meirelles, F. D. S., Filenga, D., \& Brugnolo F. M. (2014). Student satisfaction process in virtual learning system: Considerations based in information and service quality from Brazil's experience. Turkish Online Journal of Distance Education, 15(3), 122-142.

[16] Olatokun, W.M \& Mala, A. (2011). Assessing students' satisfaction with an e-learning system: The case of National Open University of Nigeria. Africa Journal of Computer \& ICTs, 5(4), 127-142.

[17] Olutola, T.A \& Olatoye. O.O. (2015). Challenges of e-learning technologies in Nigeria University Education. Journal of Educational and Social Research, 5(1), 301-305.

[18] Oye, M. S. (2011). Challenges of e-learning in Nigerian university education based on the experience of developed countries. International Journal of Managing Information Technology, 3(2), 110-112.

[19] Shaharanee, I. N. M., Jamil, J. M., \& Rodzi, S. S. M. (2016). The application of Google Classroom as a tool for teaching and learning. Journal of Telecommunication, Electronic and Computer Engineering (JTEC), 8(10), 5-8.

[20] Sun, P., Tsai, R.J., Finger, G., Chen, Y. \& Yeh, D. (2007). What drives a successful e-learning? An empirical investigation of the critical factors influencing learner satisfaction. Computers and Education, 50(4), 1183-1202

[21] UNESCO (2011). UNESCO and Education. Geneva: UNESCO Retrieved from: http://unesdoc.unesco.org/images/0021/002127/2127 15e.pdf (accessed 12 June 2017) 